\title{
Bio Pulping Of Bagasse As The Material For Paper Making Using Different Species Of White Rot Fungi And Incubation Time
}

\author{
Vio Indah Budiarti, Nuniek Ina Ratnaningtyas, Aris Mumpuni \\ ${ }^{1}$ Fakultas Biologi, Universitas Jenderal Soedirman \\ Jalan dr Suparno 63 Purwokerto 53122 \\ email : indahbudiarti3@gmail.com
}

\begin{abstract}
Rekam Jejak Artikel: Abstract
Diterima $: 28 / 08 / 2019$ The Biopulping is defined as the biological process of lignin degradation by utilizing Disetujui : $28 / 11 / 2020$ microorganisms that produce some enzymes. A microorganism which widely known in the degradation of lignin and cellulose is a group of white-rot fungi. The aims for this research to know the most effective white rot fungi species of G.lucidum, P.tuber-regium, and T.versicolor in the degradation of lignin and cellulose with different incubation time on bagasse substrate. The effectivity of biopulping indicated by the highest degradation of lignin concentration and the lowest degradation of cellulose concentration. This study used an experimental design with Completely Randomized design with a two factorial pattern. The independent variable of this study is white rot fungi species and incubation time while the dependent variable is the concentration of lignin and cellulose. The main parameter was the concentration of lignin and cellulose, supporting parameters were $\mathrm{pH}$, weight loss of substrate and mycelial growth. The result showed the degradation of lignin and cellulose in all treatment. The best degradation of lignin and cellulose showed by species T.versicolor and P.tuber-regium within 30 days of incubation.

Keyword: Bagasse; Biopulping; White Rot Fung
\end{abstract}

\section{INTRODUCTION}

Bagasse is a solid waste remnant of sugarcane (Saccharum officinarum). In general, bagasse contains lignocellulose compounds such as lignin (13-22\%), cellulose (26-43\%), hemicellulose (17-23\%), and pentose (20-33\%) (Shabiri, 2014). The waste of sugarcane mostly used as bioethanol. Bagasse and straw are mostly used for generating heat and electricity, and recently bagasse is used as paper material. The process of papermaking from bagasse can be done through biopulping (Del Rio et al., 2015).

Bio-pulping is an environmentally friendly technology which currently being developed in the pulp and paper industry. The application of biopulping in the pulp and paper industry is before the cooking process using chemicals. The pulping process pretreated with White Rot Fungi (WRF) has proven as a technology that is efficient and economically feasible, energy savings, reducing chlorine consumption and reducing pollutants into the environment and produce stronger pulp. Selective degradation or modification of native lignin in wood by WRF facilitates removal or softening in subsequent pulping processes. However, the benefits of biopulping are not proportional to the level of biodelignification or biological elimination of certain wood components in biomechanics in organosolv and kraft pulping processes (Purwita \& Hendro, 2016).

The objectives of this research were (1) to find out the interaction effect of white-rot fungi species and incubation time in the concentration of lignin and cellulose of bagasse in bio-pulping process, and (2) to find out the best optimum interaction between white-rot fungi and time of incubation in the concentration of lignin and cellulose from bagasse.

\section{MATERIALS AND METHODS}

Materials

The materials used were $G$. lucidum, $P$. tuber-regium from Asa Agro Corporation Cianjur 
collection, $T$. versicolor from Labolatory of Mycology and phytopathology Biology Faculty, bagasse of Sugarcane (Saccharum officinarum) from PT Gendhis Multi Manis, Potato Dextrose Agar (PDA), $\mathrm{H}_{2} \mathrm{SO}_{4}$, alcohol $70 \%$, distilled water, sorghum, mask, gloves, $25 \times 15 \times 0.8 \mathrm{~cm}$ polypropylene plastic bags, 50x60x0.8 cm polypropylene plastic bags.

\section{Location and Time of Research}

The research have been conducted in Mycology and Phytophatology Laboratory of Biology Faculty in University of Jenderal Soedirman, Panti Asuhan Siloam Purwokerto for field work, and Laboratory of Food Technology Science of Agricultural Faculty Universitas Jenderal Soedirman Purwokerto for analysis of lignin-cellulose concentration from January May, 2019.

\section{Design of Research}

The experimental design used in this research was Completely Randomized Design (CRD) with a Factorial pattern with 3 replication. The independent variables were three species of white rot fungi and incubation time, while the dependent variable was the degradation of lignin and cellulose. The main parameters were concentration of lignin and cellulose before and after treatment. The supporting parameters were $\mathrm{pH}$ of substrate and weight loss of bagasse before and after treatment, and mycelial growth.

\section{The procedure of Research}

The laboratory equipment was used in this research such as petri dish, reaction tubes, beaker glass, measuring glass, and other tools were sterilized using autoclave with temperature $121^{\circ} \mathrm{C}$, 2 atm, for 15 minutes (Hadioetomo, 1994). Bagasse was prepared by filtering through muslin cloth then it's dried under the sunlight for approximately 5 hours in a day until it's dry. Further, the bagasse collected into sacks. (Salbeti et al., 2018).
The commercially PDA medium powder and distilled water prepared. The distilled water was measured for $1 \mathrm{~L}$ and the PDA powder for 39 $\mathrm{g}$, then put the entire ingredient to Erlenmeyer flask. The flask boiled on a hotplate and homogenized it with a magnetic stirrer. The Erlenmeyer was covered with a cotton plug and paper, then tied with a rubber band. It was sterilized in the autoclave for $15 \mathrm{~min}$ at $121^{\circ} \mathrm{C}$, then poured into sterilized petri dish after the steam released and cooled down in LAF (Tudses, 2016).

The three species fungal isolates ( $T$. versicolor, $P$. tuber-regium and G. lucidum) were recultured into the PDA medium. The reculturation of the fungal has been done by transferred each of the fungal colonies as much as three plugs with the size of $5 \mathrm{~mm}$ using cork drill into a new PDA medium in LAF. The new PDA medium will be incubated for about 5-7 days.

\section{Fungal Spawn Inoculum Preparation (Kusnadi \& Yayan, 2003. modified).}

The fungal spawn inoculum prepared using sorghum. Five $\mathrm{kg}$ of sorghum and glass bottles in $350 \mathrm{ml}$ size prepared. Sorghum was soaked in water for two hours and the floating dirt are removed. The sorghum drained and steamed for 10 minutes, then cooling down for minutes. The $\mathrm{CaCO}_{3}$ and dextrose were measured in an analytical scale as much as $25 \mathrm{~g}$ and $50 \mathrm{~g}$ respectively, then inserted into the sorghum medium and stirred. The sorghum medium was filled into the bottle as much as $2 / 3$ from bottle size. The inoculum bottle covered with the cotton plug. They were then sterilized in the autoclave $121^{\circ} \mathrm{C}$ in 1 atm for 15 minutes. Furthermore, release the steam and wait for the cooling down.

Fungal Spawn Inoculation (Kusnadi \& Yayan, 2003, modified).

The isolates of G. lucidum, P. tuber-regium, and T.versicolor in PDA medium prepared. 
Inoculation done by forming a plug using cork borer, and take as much as five plugs of each fungal and take it into a bottle medium and wrapped the medium aseptically in LAF then incubated it for one month.

Bagasse Substrate Preparation (Suryani \& Carolina, 2017, modified).

Bagasse substrate was taken $1 \mathrm{~kg}$ and put into a container, then $1 \mathrm{~L}$ distilled water was measured and put it container and homogenized. The $\mathrm{pH}$ of the bagasse also measured using the soil tester. The bagasse substrate filled as much $200 \mathrm{~g}$ into $25 \times 20 \times 0.008 \mathrm{~cm}$ polypropylene plastic bags. The baglogs were carried out with the process of compaction. The paralon ring was given on the top of the baglog followed by putting the cotton and plastic. The bagasse substrate medium was sterilized in the autoclave for 2 hours at $121^{\circ} \mathrm{C}$. The media that has been sterilized was cooled for 12 hours before inoculation.

\section{Fungal Inoculation on Bagasse (Suryani \& Carolina, 2017, modified).}

The fungi isolated from sorghum medium was taken $10 \%$ from the weight of the bagasse substrate medium. Inoculation was done by making a deep hole approximately $2 \mathrm{~cm}$ in the middle of the baglog media using the sterilized wooden stick. Then fungal spawn was inserted into the polybag by using spatula aseptically. It's incubated in room temperature with an incubation time of 0,15 , and 30 days.

\section{Measurement pH in Bagasse Substrate}

The measurement of $\mathrm{pH}$ in the bagasse substrate was done with soil tester tools. The soil tester was dipped into bagasse medium and the $\mathrm{pH}$ measured. The measurement was done before the treatment and after treatment.

\section{Measurement of Weight Loss Media}

The weight loss measurement of bagasse substrate has been done by measuring the bagasse substrate on day 0,15 days and 30 days before and after treatment using an analytical scale.

\section{Lignin and Cellulose Analysis (Chesson, 1981)}

Determine lignin and cellulose concentration with different incubation time $(0,15$, and 30 days) was done by Chesson method.

\section{Data Analysis}

The quantitative data of the lignin and cellulose contents at the beginning and the end of treatments were analyzed using analysis of variance (F test) with the error contents is $5 \%$ and $1 \%$ followed by Duncan's Multiple Range Test (DMRT).

\section{RESULT AND DISCUSSION}

\section{Lignin Concentration}

The degradation of lignin concentration in bagasse using three species of white-rot fungi were occurred in all treatment (Table 1). The initial lignin concentration of bagasse was $17.23 \%$. Lignin concentration after 15 days and 30 days incubation time has been reduced by Ganoderma lucidum to $10.54 \%-10.88 \%$ and $10.54 \%-10.61 \%$, respectively. Pleorotus tuber-regium has reduced lignin concentration to $10.21-11.03 \%$ and $9.55 \%$ $10.21 \%$, while Trametes versicolor has reduced lignin concentration to $11.62 \%-11.71 \%$ and $9.55 \%$ $10.21 \%$, respectively.

The interaction between fungal species and incubation time significantly affect the degradation of lignin concentration as well as a factor of incubation time while the fungal species did not significantly affect to degradation of lignin concentration. It was then followed by Duncan Multiple Range Test (DMRT) with level 5\%, as it is seen on Table 1 . 
Table 1. Duncan Multipe Range Test on the interaction of WRF species and incubation time on lignin concentration $(\%)$

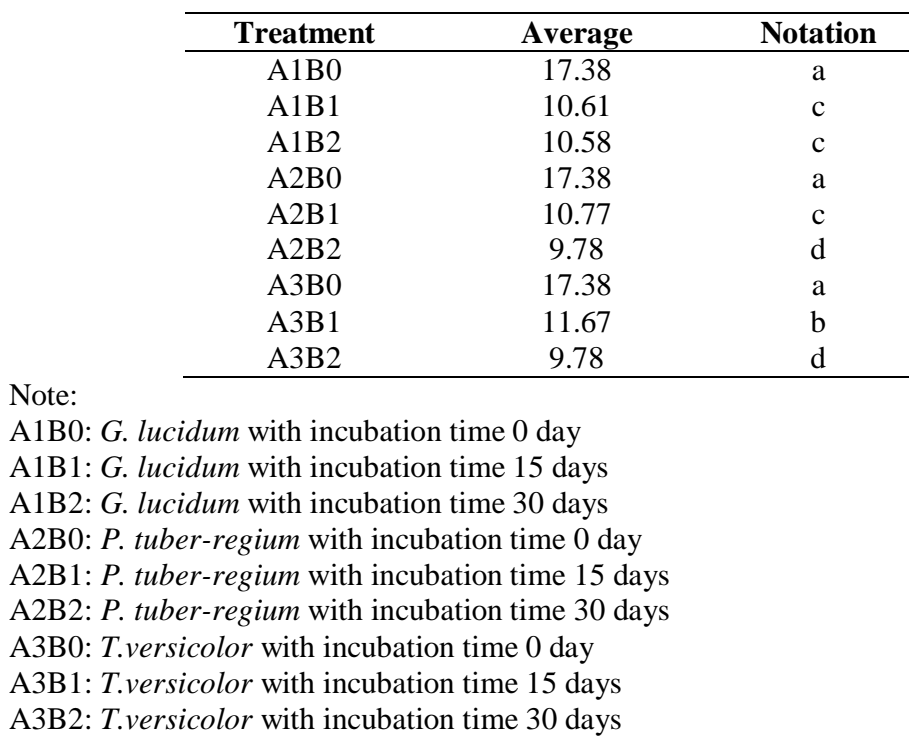

Note:

The treatment of $\mathrm{A} 2 \mathrm{~B} 2$ and $\mathrm{A} 3 \mathrm{~B} 2$ were the most effective fungi ( $P$. tuber-regium and $T$. versicolor) and incubation time (30 days) to degrade lignin from bagasse, reducing its concentration from $17.38 \%$ to $9.78 \%$ (Table 1). The previous studies reported that $T$. versicolor had a high delignification rate after 14 days of wheat straw fermentation, while levels of the analyzed ligninolytic enzyme activities were similar or even lower (Knezevic et al. 2013). Trametes species are well recognized as good laccase producers, especially in a copper-enriched substrate. Other research reported that $T$. versicolor able to degrade lignin concentration on hemp with $15.4 \%$ after 7 days incubation (Hossain \& Anantharaman 2006). T.versicolor also showed the ability to produce three types of ligninolytic enzymes such as LiP, $\mathrm{MnP}$ and laccase with the dominated of enzyme activity by LiP. According to Ćilerdžić et al, (2017), the study of degradation of lignin in wheat straw using G. lucidum showed 38\% degradation within 21 days incubation. Jonathan et al. (2008), investigated that $P$. tuber-regium able to degrade the waste wood. The greatest lignin degradation was noticed in the sawdust of Holoptelia grandis within 0, 30, 60 and 90 incubation days (from $83.33 \%$ to $24.00 \%$ ).

The highest degradation showed by. $T$. versicolor and P.tuber-regium, both of the fungal reported have the capability in producing $\mathrm{LiP}, \mathrm{MnP}$ and laccase enzymes. The laccase enzyme activity in T.versicolor is higher among the three enzymes while in P.tuber-regium the MnP enzyme activity was significantly higher than LiP and laccase activities (Asif et al., 2017; Nwogu et al., 2012). Yanru et al. (2016), G. lucidum has the ability to produce lignocellulolytic enzymes such as peroxidase or laccase which can degrade cellulose, hemicellulose and lignin. This is in accordance with the statement of Mtui (2012). Lignin peroxidase (LiP) has different immunological and structural characteristics from manganese IIdependent peroxidase (MnP), which has the ability to oxidize important bonding members in lignin. In contrast, the role of $\mathrm{MnP}$ in lignin degradation has been suggested as indirect by providing $\mathrm{H}_{2} \mathrm{O}_{2}$ for the lignin peroxidase reaction (Hossain \& Anantharaman, 2006). The three ligninolytic enzymes, LiP, MnP and laccase work by different mechanisms. LiP was degraded non-phenolic lignin units, while MnP degraded on phenolic and non- 
phenolic lignin units through lipid peroxidation reactions, oxidizing $\mathrm{Mn}^{2+}$ to $\mathrm{Mn}^{3+}$ which oxidizes the phenol ring to radicals phenoxy which lead to degradation of lignin. Laccase catalyzes the oxidation of phenolic units in lignin and phenolic compounds. The potential of laccase to degrade lignin is increased by acid phenolic compounds which will act as redox mediators. Without the role of redox mediators, the impact is limited (Saloheimo \& Nikku-Paavola, 1991).

The longer the incubation time the more effect to degradation of lignin concentration. Incubation time play a vital role in degradation lignin and cellulose. Each fungal species has optimal enzyme activity in degrade lignin and cellulose concentration, certain incubation time is needed to optimize ligninolytic enzyme activity. According to Krik \& Chang (1990), the optimum incubation time is a factor that allows good bio delignification in sengon wood sawdust. The best incubation time is the incubation time which results in the optimum decrease in lignin, resulting better degradation process.

\section{Cellulose Concentration}

The degradation of cellulose concentration in bagasse using three species of WRF and different incubation time also showed the degradation in cellulose concentration. The initial cellulose concentration of bagasse was $23.64 \%$. The degradation by G. lucidum during 15 and 30 days has reduced cellulose concentration of bagasse to $16.66-18.06 \%$ and $18.83-20.17 \%$, respectively. Species $P$. tuber-regium has reduced cellulose concentration to $18.92-22.08 \%$ and $19.93-22.75 \%$ while species T.versicolor has reduced cellulose concentration to $19.53-22.16 \%$ and $22.16-22.99 \%$ respectively. The interaction of the three species of white-rot fungi and incubation time affected degradation of cellulose concentration, as well as the factor of incubation time and the factor of WRF species (Table 3).

The interaction between incubation time and WRF showed a significant effect on the amount of degraded lignin and cellulose. The degradation of cellulose concentration in bagasse indicated that WRF is an organism which not only capable of completely degrading lignin into $\mathrm{CO}_{2}$ and $\mathrm{H}_{2} \mathrm{O}$. Its uniqueness in degrading lignin is very selective so it does not damage cellulose fibers relatively and fungal groups that produce ligninolytic enzymes (Risdianto et al., 2007). The result of the analysis of variance in showed that the interaction between fungal species and incubation time significantly affects the degradation of cellulose concentration as well as a factor of incubation time and fungal species (Table 2). It was then followed by Duncan Multiple Range Test (DMRT) with level 5\%, as it is seen on Table 3.

Table 3. Duncan Multiple Range Test on the interaction of WRF species and incubation time on cellulose concentration (\%)

\begin{tabular}{ccc}
\hline Treatment & $\begin{array}{c}\text { Average/Standart } \\
\text { Deviation }\end{array}$ & Notation \\
\hline A1B0 & $23.64 / 0.000$ & $\mathrm{a}$ \\
A1B1 & $17.59 / 0.4973$ & $\mathrm{e}$ \\
A1B2 & $19.75 / 0.2409$ & $\mathrm{~cd}$ \\
A2B0 & $23.64 / 0.000$ & $\mathrm{a}$ \\
A2B1 & $19.176 / 0.3120$ & $\mathrm{~d}$ \\
A2B2 & $19.753 / 0.2468$ & $\mathrm{~b}$ \\
A2B0 & $23.64 / 0.000$ & $\mathrm{a}$ \\
A3B1 & $19.946 / 0.493$ & $\mathrm{c}$ \\
A3B2 & $22.47 / 0.2502$ & $\mathrm{~b}$ \\
\hline
\end{tabular}

Note:

A1B0: G. lucidum with incubation time 0 day

A1B1: G. lucidum with incubation time 15 days

A1B2: G. lucidum with incubation time 30 days A2B0: P. tuber-regium with incubation time 0 day A2B1: $P$. tuber-regium with incubation time 15 days A2B2: P. tuber-regium with incubation time 30 days A3B0: T.versicolor with incubation time 0 day A3B1: T.versicolor with incubation time 15 days A3B2: T.versicolor with incubation time 30 days

The effectivity of biopulping showed by the highest reduction of lignin and the lowest reduction of cellulose concentration. The DMRT of cellulose concentration in bagasse (Table 3.) showed that the interaction between WRF species and incubation time was significantly different in 
the degradation of cellulose content. The most significant treatments were showed by A2B2 $(P$. tuber-regium, incubation time 30 days) that lowered cellulose concentration from $23.64 \%$ to $19.753 \%$; and A2B3 (T. versicolor, incubation time 30 days) that reduced cellulose concentration from $23.64 \%$ to $22.47 \%$. The degradation of cellulose concentration may happen because of the ability of WRF in producing enzymes and the utilization of cellulose as their carbon source (Rouches et al., 2016). Cellulose contains about 50-90\% of the crystallized part and amorphous (Aziz et al., 2002).

The fungi could degrade cellulose by producing a group of cellulolytic enzymes that work synergistically. The rate of degradation of polysaccharides and lignin from the substrate can differ between species of white-rot fungi. According to Solar et al. (2006) \& Aguiar et al. (2014), T. versicolor had ability to degrade lignin and cellulose loss resulting from bio-treatment. The Degradation of cellulose using T.versicolor and beech wood as the substrate showed the degradation of cellulose in 15 days is $53.57 \%$ while in 30 days of incubation time is $54.26 \%$. Degradation of cellulose, similarly as in the case of lignin, proceeded since the early stages. The cellulose degradation caused fungal used the cellulose and lignin as a source of carbon.

According to Kuforiji \& Fasidi (2009), the degradation of P.tuber-regium using different waste showed degradation of cellulose. The cellulose degradation of Rice straw showed the initial concentration from $38.6 \%$ to $31.5 \%$ while in cocoyam waste the degradation of cellulose concentration showed from $50 \%$ to $42.5 \%$ after 3 weeks incubation time. Adinipekun et al. (2012) reported that hemicelluloses and celluloses reduced when Pleurotus tuber-regium was used during biodegradation of agro industrial wastes. The degradation of cellulose concentration from
$8.90 \%$ to $6.40 \%$ in rattan wood. The degradation of cellulose concentration based on incubation time. Fadilah (2008) reported that degradation of cellulose reaches $22.3 \%$ within 30 days of incubation time on leaf stem as a substrate. The longer incubation time the greatest reduction of cellulose. The incubation time play important role in degradation of cellulose concentration.

The incubation time has large influence in the degree of milling and strength of pulp. The previous study showed that incubation of 12-14 days produced a better quality of pulp compared to 10 days of incubation (Septiningrum \& Ikhwan, 2017). The utilization of fungi in biopulping process can reduce the use of chemical substances, reduce the cooking time on chemical pulping, modified the specific fibers and improve the physical properties of pulp sheets such as tensile resistance and bursting resistance. Increased physical properties of these paper can occur because fungi are able to increase external fibrillation and internal fiber (Yang et al., 2007). The efficiency of fungi in the bio pulping process depends on several factors, such as the type of fungal species, incubation time, $\mathrm{pH}$ and temperature.

Table 4. The Average $\mathrm{pH}$ and Weight of Bagasse Substrate

\begin{tabular}{ccccccc} 
& \multicolumn{3}{c}{ Substrate } \\
\hline \multirow{2}{*}{$\begin{array}{c}\text { Isolate } \\
\text { code }\end{array}$} & \multicolumn{3}{c}{$\mathrm{pH}$} & \multicolumn{3}{c}{ Weight of Bagasse (g) } \\
\cline { 2 - 7 } & 0 & 15 & 30 & 0 & 15 & 30 \\
\hline & 6.8 & 6.5 & 5.43 & 200 & 195.3 & 190.3 \\
GL & 6.8 & 6.5 & 5.26 & 200 & 196.3 & 193.5 \\
PT & 6.8 & 6.6 & 5.7 & 200 & 194.3 & 192.3 \\
TV & & & & & \\
Note: & & & & & \\
GL: G.lucidum & & & & & \\
PT: P.tuber-regium & & &
\end{tabular}

The initial $\mathrm{pH}$ was 6.8. After 15 days of incubation the average $\mathrm{pH}$ of G. lucidum, P.tuberregium and T.versicolor ranged between 6.5 -6.6 while the treatment of 30 days incubation showed that the average $\mathrm{pH}$ was 5.43 - 5.7(Table 4). These $\mathrm{pH}$ values are suitable for the growth of the fungi. 
Generally, the value of $\mathrm{pH}$ for fungal growth ranges between 5-6. According to Away et al. (2000), to utilize hemicellulose, cellulose and lignin as a source carbon, the fungi should secrete enzymes. The action of enzymes influenced by several factors such as substrate, $\mathrm{pH}$, cofactor, and inhibitor. Each enzyme have different optimum $\mathrm{pH}$ and temperature. Enzymes are proteins, which can change shape if the temperature and acidity change. Beyond the appropriate temperature or $\mathrm{pH}$ value, the enzyme cannot work optimally or the structure will be damaged. Besides $\mathrm{pH}$, temperature also plays an important role in the production of the enzyme lignin peroxidase. Each fungi has a different optimum, minimum and maximum temperature for growth. Growth at temperatures below the optimum temperature can reduce the average cell metabolism. Temperature above the optimum, causing growth to decline and the possibility of death if it exceeds the maximum temperature. Table 4 showed weight loss of bagasse before and after treatment. The initial weight of bagasse substrate was $200 \mathrm{~g}$, then after 15 days incubation time, the weight of bagasse decreased. Species T.versicolor showed the highest weight loss of bagasse with an average of $194.3 \mathrm{~g}$. After 30 days of incubation, the species of G.lucidum showed the best treatment with an average of bagasse weight is $190.3 \mathrm{~g}$. The weight loss of bagasse substrate caused by the fungal that utilize the component of bagasse such as lignin, cellulose and hemicellulose as their carbon source. According Septiningrum \& Ikhwan (2017), the fungal degradation of lignin and cellulose affected to pulp yield as much $12.3 \%$.

\section{CONCLUSION}

Based on research result and discussion, it can be taken conclusions are the following that the interaction of white rot fungi species and incubation time affected in lignin and cellulose degradation of bagasse in bio-pulping process. the best interaction between white rot fungi and time of incubation to degradation of lignin concentration from bagasse was fungal species of P.tuber-regium and T.versicolor within 30 days of incubation time, while the best interaction between white rot fungi and time of incubation to degradation of cellulose concentration from bagasse was fungal species of P.tuber-regium and T.versicolor within 30 days of incubation time.

\section{REFERENCES}

Adinipekun, C.O.,Okunlade, O.A., Ogunjobi, A.A. 2012. Effect of Pleorotus tuber-regium Singer on degradation of rattan wood and maize stozers. Journal of Applied Biosciences, 51: 3633-3641.

Aguiar, A., Gavioli, D., \& Ferraz, A. 2014. Metabolite secretion, Fe3+-reducing activity and wood degradation by the whiterot fungus Trametes versicolor ATCC 20869. Fungal Biology. 118(11): 935-942.

Asif, M.B., Hai, F.I., Singh, L., Price W.E., dan Nghiem, L.D. 2017. Degradation of Pharmaceuticals and Personal Care Products by White-Rot Fungi - A Critical Review. Curr Pollution Rep.

Away, Y., Goenadi, D. H., Pasaribu, R. A., Santosa, G.I. 2000. Biopulping Tandan Kosong Kelapa Sawit. Bogor: Unit Penelitian Bioteknologi Perkebunan.

Aziz, A.A., M. Husin \& A. Mokhtar. 2002. Preparation of cellulose from oil palm empty fruit bunches via ethanol digestion: effect of acid and alkali catalysts. Journal of Oil Palm Research, 4(1): 9-14.

Chesson, A. 1981. Effects of sodium hydroxide on cereal straws in relation to the enhanced degradation of structural polysaccharides by rumen microorganisms. J. Sci. Food Agric, $32: 745-758$.

Del Rio, J. C., Alessandro, G. L., Jorge, L. C., Claudio, F. L., Ana, G ,E., Angel, T. M., Fachuang, L., John, R., Jorge, R. 2015. Differences in the chemical structure of the lignins from sugarcane bagasse and straw. Biomass \& Bioenergy, 81: 322-338.

Hadioetomo, R.S. 1985. Mikrobiologi Dasar dalam Praktek Teknik dan Prosedur Dasar Laboratorium. Jakarta: Gramedia.

Hossain, S.K. M., Anantharaman, N. 2006. Activity enhancement of ligninolytic enzymes of Trametes versicolor with bagasse powder. 
African Journal of Biotechnology, 5 (1): 189-194.

Jonathan, S. G., Fasidi, I. O., Ajayi, A. O., \& Adegeye, O. 2008. Biodegradation of Nigerian wood wastes by Pleurotus tuberregium (Fries) Singer. Bioresource Technology, 99, pp. 807-811.

Knezevica, A., Ivan, M., Mirjana, S., Nikola, L., Ilija, B., Jelena, V., Jasmina, C. 2013. Lignin degradation by selected fungal species. Bioresorce Technology, 138 : 117123.

Krik, T. K. \& H., M. Chang., 1990. Biotechnology in Pulp and Paper Manufacture. USA : Butterwort-Heineman.

Nwogu, N.A., Atuanya. E., Akpaja, E.O. 2012. Capability of selected mushrooms to biodegrade polyethylene. Mycosphere 3(4) : 455-462

Purwita, C, A., Hendro, R. 2016. Pengaruh Aplikasi Jamur Pelapuk Putih Pada Biopulping Rami (Boehmeria Nivea) Terhadap Kualitas Pulp Belum Putih. Jurnal Selulosa, 6 (2) : 105-144.

Risdianto, H., Tjandra, S., sri, H. S., Wardono, N. 2007. Pemilihan Spesies Jamur dan Media Imobilisasi untuk Produksi Enzim Ligninolitik. Bandung : Prosiding Seminar Nasional Rekayasa Kimia dan Proses.

Rouches, E., Herpoël-Gimbert, I.., P. Steyer., H. Carrere. 2016 Improvement of anaerobic degradation by white-rot fungi pretreatment of lignocellulosic biomass: A review. Renewable and Sustainable Energy Reviews, 59 : 179-198.

Salbeti, D., Harlia.,Intan, S. 2018. Sintesis Dan Karakterisasi Termal Plastik Ramah Lingkungan Polyblend Selulosa Ampas Tebu Dan Limbah Botol Plastik Polietilen Tereftalat. Jurnal Kimia Khatulistiwa, 7(2): 54-60.

Septiningrum, K., Ikhwan, P. 2017. Aplikasi Enzim Di Industri Pulp Dan Kertas: I. Bidang Pulp. Jurnal Selulosa, 7(1) : 1-16.

Shabiri, A.N., Ritonga, R.S., Ginting, M.H.S., 2014. Pengaruh Rasio Epoksi/Ampas Tebu Dan Perlakuan Alkali Pada Ampas Tebu Terhadap Kekuatan Bentur Komposit Partikel Epoksi Berpengisi Serat Ampas Tebu. Jurnal Teknik Kimia USU, 3(3): 2831.

Saloheimo M., \& Niku-Paavola M.L. 1991. Heterologous production of a ligninolytic enzyme: expression of the Phlebia radiata laccase gene in Trichoderma reesei. Biotechnol, 9 : 987-990.
Solar, R., Stanislav, K. Miroslav, M., Eva, N., Joze, H. 2006. Wood Structure and Properties: Selected Chemical And Physical Properties Of Beech Wood Degraded By Wood Destroying Fungi. Slovakia: Arbora Publisher

Tudses. 2016. Isolation and Mycelial growth of mushroom on different yam based on culture media. Journal of Applied Biology \& Biotechnology,4 (05) : 033-036.

Yang, Q.H., Zhan, S., Wang, S., Fu, K. L. 2007. Bio-modification of eucalyptus chemithermo-mechanical pulp with different white-rot fungi. Bioresource, 2 (4) : 682-692 